\title{
Zika Virus and Global Implications for Reproductive Health Reforms
}

\author{
James G. Hodge, Jr, JD, LLM; Alicia Corbett, JD; Ashley Repka; P. J. Judd
}

$\mathrm{T}$ he rapid global spread of Zika virus, especially in developing countries in Latin America, presents new and significant risks to the public's health, notably among pregnant women and their infants. Zika virus is predominantly spread via the Aedes species of mosquitos, but sexual transmission between infected males and their female partners has also been shown. While related morbidity of Zika virus remains uncertain, credible evidence is growing of the link between infection of women and potentially disabling mental and physical impairments of their fetuses. Public health scientists are virtually sure that increased rates of microcephaly (abnormally small skulls and brains) among thousands of Brazilian infants over the past several months are tied to Zika infection. ${ }^{1}$ New evidence of vision, hearing, and long-term mental health disabilities among Zika-affected babies is also mounting. ${ }^{2}$

Facing these threats to vulnerable mothers and infants, public health authorities and government leaders in multiple countries have issued first-ever recommendations for women to simply avoid pregnancy for months, years, or even indefinitely. Not only is the efficacy of this public health guidance unproven, its legality and ethicality are highly suspect. In many of these countries, women experience significant rates of sexual violence. Their access to contraceptives or abortions to terminate at-risk pregnancies due to Zika virus is legally restricted or practically unavailable. As discussed below, the resulting implications for women's reproductive rights are profound.

\section{PUBLIC HEALTH RECOMMENDATIONS TO LIMIT REPRODUCTION}

The suspected link between Zika infections among pregnant women and microcephaly among infants has elevated this virus into a global menace. On February 1, 2016, the World Health Organization (WHO) declared Zika virus a public health emergency of international concern due largely to its morbidity among infants. Latin American countries impacted directly by the virus reacted initially with extensive public outreach and mosquito abatement efforts. Still, Zika virus has continued to spread explosively. Brazil has already experienced over 1.5 million cases. WHO estimates that potentially 4 million people in the Americas may become infected in 2016. Lacking cures or available vaccines and facing potentially thousands of cases of infant morbidity, select countries have taken the unprecedented step of advising women to avoid pregnancy.

In late 2015, Brazilian health officials began warning women to avoid pregnancy until the Zika virus epidemic passes. ${ }^{1}$ Governments in Colombia and Ecuador made similar recommendations in January 2016 for women to delay pregnancy between 6 and 8 months. ${ }^{3}$ Recommendations in El Salvador are even more extreme. With standing water and trash providing plentiful breeding areas, and gang violence restricting access to some dense, urban areas, El Salvadoran health officials' efforts to control mosquitos have been thwarted. Consequently, women there have been advised to avoid pregnancy until 2018. ${ }^{4}$ Given the dubious viability of these recommendations in preventing future infant morbidity, women in these countries find themselves at the epicenter of an emerging public health strategy of questionable efficacy.

\section{LEGAL REPRODUCTIVE RIGHTS IN SELECT NATIONS}

Recommending against pregnancy for extensive periods of time is not purposeful if women lack access to effective contraceptives or safe abortions. In many Latin American countries, access to reproductive health services is limited compared to developed countries like the United States. Most forms of contraception are legal in these countries, except for emergency contraception (eg, "morning after" pill) in places like Honduras. ${ }^{5}$ However, legality does not imply widespread access or use. Among select countries currently advising against pregnancy, the rates of modern contraceptive prevalence range from $64 \%$ in El Salvador to $75 \%$ in Brazil (as of 2013). ${ }^{5}$ That is, less than two-thirds of El Salvadoran women aged 15 to 49, or their partners, used a modern form of contraception (eg, condom, "the pill," IUD). These rates are based primarily on women who are married or with a stable partner; considerably less is known about contraceptive access among single women living in different environments. Use is constrained as well by intermittent unavailability of contraceptives in El Salvador and other countries. $^{5}$ 
When contraception is either not available or fails to prevent pregnancy, abortion is an alternative for women in countries like the United States. However, legal access to abortion in Latin America varies. Colombia authorizes abortions only in certain cases, such as risk to the mother's life or health, rape, incest, or pregnancies involving fatal or life-threatening fetal abnormalities. ${ }^{6}$ In El Salvador, there is no legal right to abortion, even when the life of the mother is threatened. Brazil falls between these 2 examples. Its laws currently allow abortion in the case of risk to the mother's life, rape, incest, and anencephaly. ${ }^{6}$

Abortion restrictions are compounded by difficulties in diagnosing microcephaly and other Zika-related illnesses passed from mother to child. Microcephaly cannot be diagnosed definitively via ultrasound until 20 to 24 weeks into a pregnancy, which approaches the cutoff for access to abortions even under more liberal allowances in the United States. Additionally, potential mental health disabilities and vision or hearing limitations triggered by Zika virus among affected infants may not be diagnosed for months or years after birth.

\section{DIVERGENCES BETWEEN PUBLIC HEALTH RECOMMENDATIONS AND LEGAL REPRODUCTIVE RIGHTS}

In countries that lack other preventive public health options, foregoing pregnancy may appear to be a sensible precaution against microcephaly or other infant disabilities stemming from Zika virus. However, these public health recommendations place women in difficult situations due to their insufficient reproductive rights and limited access in some countries. Modern forms of contraception may be legal in most Latin American nations, but they are not universally available or utilized, especially in rural or poorer areas. ${ }^{5}$ Many women may feel disempowered to seek contraception, be unable to require their sexual partners to use condoms (due to sexual violence or other determinants), or lack awareness of modern contraceptive options. ${ }^{7}$ If more people heed recommendations to delay pregnancy, demand for contraceptives may result in greater scarcity and less access.

Beyond issues of access, considerable numbers of Latin American women may oppose the use of contraceptives based on their traditional Catholic beliefs, which prohibit abortion and many forms of contraception. ${ }^{8}$ Pope Francis recently stated that contraception, but not abortion (which is never the "lesser of evils"), could be acceptable under the extraordinary public health circumstances of the spread of Zika virus. ${ }^{9}$ Whether the Pope's allowance will prompt more women to obtain and utilize modern contraception in the affected regions is yet to be seen.

Pregnant women infected with Zika virus face uncertain outcomes related to their babies' health. Some countries do not explicitly recognize a right to abortion in these circumstances, ${ }^{5}$ which increases risks to women's health among those seeking illicit and unsafe abortions. Unsafe abortions accounted for $10 \%$ of all maternal deaths in Latin America and the Caribbean in $2014 .^{6}$

Increasing awareness and counter-arguments to existing anti-abortion laws have arisen in Colombia and Brazil in light of Zika virus. ${ }^{7}$ Some Colombian medical officials posit that a pregnant woman's diagnosis with Zika virus could be acceptable grounds for abortion under existing laws. Reproductive rights advocates in Brazil are planning to ask their Supreme Court to include a pregnant woman's diagnosis with Zika virus as a legal justification for abortion. Whether this request comports with public opinion is less certain. In a 2014 poll, nearly $80 \%$ of Brazilians were against further legalizing abortion. $^{7}$ As well, some Brazilian legislators have proposed to increase penalties for illegal abortions even as Zika virus spreads across their country.

\section{CONCLUSION}

The juxtaposition of women's reproductive rights and public health recommendations to avoid pregnancy in response to Zika virus is profound. Lack of contraception coupled with restrictive stances on abortion and rates of sexual violence or inequity do not bode well for a public health strategy relying on voluntary choices among disempowered women. Absent shifts in public opinion and legal frameworks, limited reproductive rights in Latin America may stymie public health recommendations. Meaningful reforms should promote and empower healthy options based on principles of sexual equity and the public's health.

\section{About the Authors}

Sandra Day O'Connor College of Law, Arizona State University, Tempe, Arizona.

Correspondence and reprint requests to James G. Hodge, Jr, JD, LLM, Professor of Public Health Law and Ethics, ASU Sandra Day O'Connor College of Law, Ross Blakeley Library, Room 318, PO Box 877906, Tempe AZ 85287-79906 (e-mail: james.hodge.1@asu.edu).

Published online: March 9, 2016.

\section{REFERENCES}

1. Barchfield J. Officials in Brazil urge women to avoid pregnancy due to Zika virus. Boston Globe. https://www.bostonglobe.com/news/world/ 2016/01/26/officials-brazil-urge-women-avoid-pregnancy-due-zika-virus/ Ask7wAjozV0G6SCv80uK8N/story.html. Published January 26, 2016. Accessed March 1, 2016.

2. McNeil D. Zika may increase risk of mental illness, researchers say. New York Times. http://www.nytimes.com/2016/02/23/health/zika-mayincrease-risk-of-mental-illness-researchers-say.html?_r=0. Published February 18, 2016. Accessed March 1, 2016.

3. Colombia reports more than 2,100 pregnant women have Zika virus. New York Times. http://www.nytimes.com/2016/01/31/world/americas/ colombia-reports-more-than-2100-pregnant-women-have-zika-virus.html. Published January 30, 2016. Accessed March 1, 2016. 
4. Ahmed A. El Salvador's advice on Zika virus: Don't have babies. New York Times. http://www.nytimes.com/2016/01/26/world/americas/ el-salvadors-advice-on-zika-dont-have-babies.html?_r=0./. Published January 25, 2016. Accessed March 1, 2016.

5. Kates A, Michaud J, Valentine A. Zika Virus: The Challenge for Women. Kaiser Family Foundation website. http://kff.org/global-health-policy/ perspective/zika-virus-the-challenge-for-women/. Published February 1, 2016. Accessed March 1, 2016.

6. Guttmacher Institute. Facts on Abortion in Latin America and the Caribbean. Guttmacher Institute website. https://www.guttmacher.org/ pubs/IB_AWW-Latin-America.pdf. Published November 2015. Accessed March 1, 2016.
7. Katz JM. The dilemma of Zika: Pregnancy warnings rise in a region lacking contraception. STAT. http://www.statnews.com/2016/02/01/zika-pregnancywarnings-latin-america/. Published February 1, 2016. Accessed March 1, 2016.

8. Brown L. Head of UN Women: Expand 'Reproductive rights' in Zikaaffected Countries 'Not only because of Zika' but it's the 'Right thing to do.' CNS News. http://www.cnsnews.com/news/article/lauretta-brown/ head-un-women-expand-reproductive-rights-zika-affected-countries-not. Published February 23, 2015. Accessed March 1, 2016.

9. Rocca FX. Pope Francis says contraception can be acceptable in regions hit by Zika virus. The Wall Street Journal. http://www.wsj.com/articles/popefrancis-says-contraception-justified-in-regions-hit-by-zika-virus-1455814800. Published March 1, 2016. Accessed March 1, 2016. 